\title{
THE EXPRESSION OF THE POTENTIAL OF LITHUANIAN MUNICIPALITIES IN DEVELOPING A SMART SOCIAL SYSTEM
}

Tomas Martinaitis, Master of Public Governance, Tomas Martinaitis, Vilnius University Šiauliai Academy, Lithuania, tomartinaitis@gmail.com

\begin{abstract}
The article analyses the expression of the potential of Lithuanian municipalities in developing a smart social system. The focus is on defining the concepts of a smart social system and a smart region. Based on the authors' works, the article presents the trajectory of the change of smart local self-governance, in the case of Lithuanian municipalities. It has been established that the change towards a smart social system can be achieved through five investment directions: human resources, digital economy and business, innovation and research, economic infrastructure and climate change, and energy. Such insights are based on the statements of expert interviews and Lithuania's plan for the DNA of the future economy.
\end{abstract}

Key words: smart social system, smart region, smart municipality, municipal potential

\section{INTRODUCTION}

In today's world, countries face many new challenges posed by globalization as well as demographic, social, economic, and technological changes. With the decreasing of social cohesion, distrust of traditional authorities, financial market instability, demographic change and migration, the social system needs to be restructured and sustainable economic growth needs to be ensured. The pressure on national and local authorities to find appropriate ways of managing and organizing the activities of governance and the public sector, to address socio-economic problems quickly and efficiently is increasing [1].

Buškevičiūtè [2], quoting Jucevičienė and Jucevičius [3], provided the following definition of smartness: "Smartness is the ability to quickly and ingeniously adapt to the conditions of a changing environment by making adequate decisions and using them to achieve the ultimate goal."

The modern challenges facing public administration subjects, even more pronounced in the face of the Covid-19 crisis, are forcing them to look for new and effective ways to solve 
problems and achieve their goals. Therefore, this study actualizes the expression of municipalities as dimensions of a smart social system and the possible trajectory of change.

To achieve this, the concepts of smart social systems and smart region will be presented at the beginning of the article, then, using the data of the performed empirical research and taking into consideration the DNA plan of the future economy presented by the Government of the Republic of Lithuania in June 2020, the trajectory of the change in the expression of the potential of Lithuanian municipalities will be proposed.

\section{DIMENSIONS AND CHARACTERISTICS OF SMART SOCIAL SYSTEM}

Today, the term "smartness" is often used in academic research in collocations with different words to mean the common presence of people, activities: "state", "region", "city", "society", "community", and "economy" [4].

All of these terms have a common determinant: they are social systems. Jucevičienè and Jucevičius [4], having analysed the concept of smartness not only in the context of the individual, but also in the context of social systems, presented the following definition of smartness: "Smartness is the ability to see critical features or their system, to react quickly and ingeniously to the important factors that they determine: challenges, opportunities, trends or symptoms, using them to achieve their goals and make decisions based on social responsibility." [5].

The term "smartness" is most commonly used in the context of social systems such as Smart City, Smart Region, Smart Community or Smart Country [6]. In most cases, smartness is analysed from the aspect of social systems, trying to highlight the essential characteristics of a smart social system and to underline the most important features of such a system. Jucevičius and Jucevičienè [4] identified the essential dimensions of smartness that must be characterized by any smart social system, regardless of its size (organization, city, region, country), nature and scope of activities, goals or other characteristics (Fig. 1).

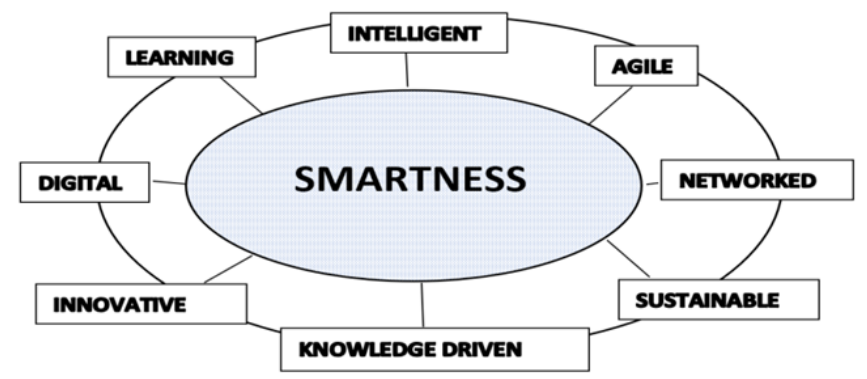

Fig. 1 Dimensions of smartness, Source: [4] 
Stanislovaitienè [6] presented the dimensions of the smart social system slightly differently, calling them characteristics (Table 1):

Table 1. Characteristics of the smart social system, Source: [6]

\begin{tabular}{|c|c|}
\hline $\begin{array}{l}\text { Characteristics of the } \\
\text { smart social system }\end{array}$ & Content \\
\hline Intelligent & $\begin{array}{l}\text { It is a system that is able to scan and use the information received (both externally } \\
\text { and internally within the social system) to achieve its goals. }\end{array}$ \\
\hline Knowledge-driven & $\begin{array}{l}\text { It is a system that, on the basis of the information received, is able to generate the } \\
\text { knowledge needed to make decisions and gain a competitive advantage. }\end{array}$ \\
\hline Learning & $\begin{array}{l}\text { A system that enables the continuous learning of individuals, their groups and } \\
\text { networks, based not only on experience but also on the ability to see and anticipate } \\
\text { the future. }\end{array}$ \\
\hline Networked & $\begin{array}{l}\text { A system whose members have the opportunity to take advantage of the } \\
\text { opportunities offered by different types of networks, to communicate with other } \\
\text { social systems and individuals, to obtain resources important to the social system } \\
\text { and to achieve their goals. }\end{array}$ \\
\hline Innovative & $\begin{array}{l}\text { A system that promotes creativity and is able to create new and non-standard } \\
\text { solutions in system-relevant internal and external business processes. }\end{array}$ \\
\hline Agile & $\begin{array}{l}\text { A system that is able to achieve its goals by responding quickly to changes caused } \\
\text { by the external and internal environment. }\end{array}$ \\
\hline Sustainable & $\begin{array}{l}\text { A system that is able to align environmental, economic and socio-cultural } \\
\text { dimensions in decision-making and implementation. }\end{array}$ \\
\hline Digital & $\begin{array}{l}\text { A system in which information-communication technologies are widely used to } \\
\text { obtain information, communication, networking, substantiate, make and implement } \\
\text { decisions. }\end{array}$ \\
\hline Socially responsible & $\begin{array}{l}\text { A system that takes responsibility for its decisions, contributes to sustainable } \\
\text { development and is based on values recognized by society. }\end{array}$ \\
\hline
\end{tabular}

Summarizing the concepts of the smart social system presented in both sources, it can be stated that the smart social system, in order to achieve its goals, should respond quickly and creatively to significant environmental factors: challenges, opportunities, trends or symptoms, aligning them with social responsibility.

\section{SMART REGION}

As the challenges of modern society have become more complex, regions have to adapt to the current situation and look for the most appropriate ways to develop. In order to increase the quality of life of its members, each region's community has to find a unique set of actions based on its internal strengths, which would help it to envisage and respond to critical signs 
of changes in the internal and external environment on time, needs, potential and opportunities, and to adopt and implement solutions, to respond successfully to challenges [7]. Namely the arising challenges are forcing local authorities to look for smarter solutions.

Seeking positive performance and the well-being of society requires smart regional governance. Smart regional governance can be defined as a kind of governance approach or form of governance that is based on the principles of good governance and enables the social system to operate effectively in a highly complex dynamic environment, using the intellectual capital of this system and its environment [2].

Sinkienè and Grumadaite [7] proposed the conceptual model of a smart region (Fig. 2).

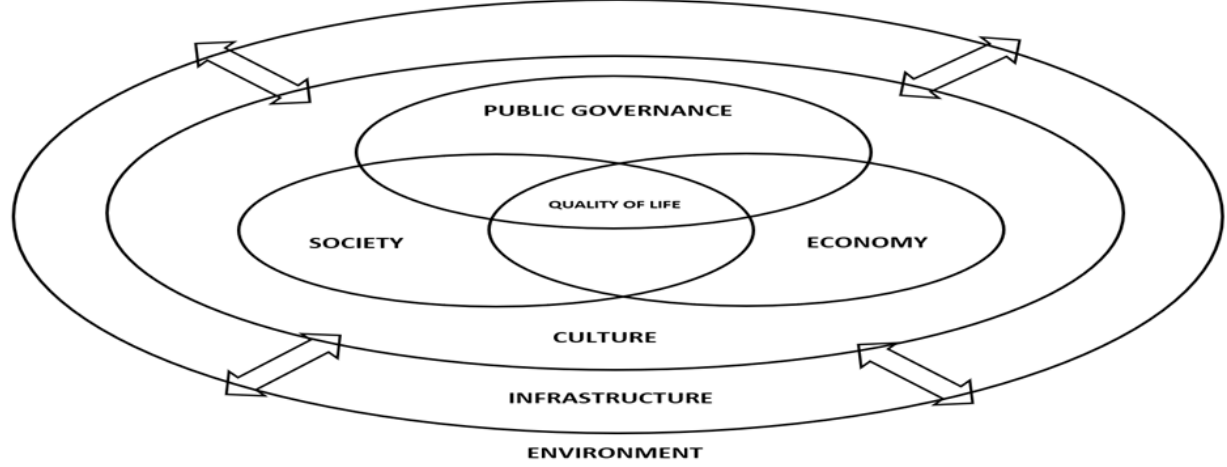

Fig.2 Smart region model, Source: [7]

This model has a number of similarities with the visual model of the three areas of smartness of the Lithuanian progress strategy (Fig. 3). In their model of the smart region, the authors have underlined three areas: Society, Economy and Public Governance. The model of Lithuania's progress strategy distinguishes the following components: Smart society, Smart economy, Smart public governance.

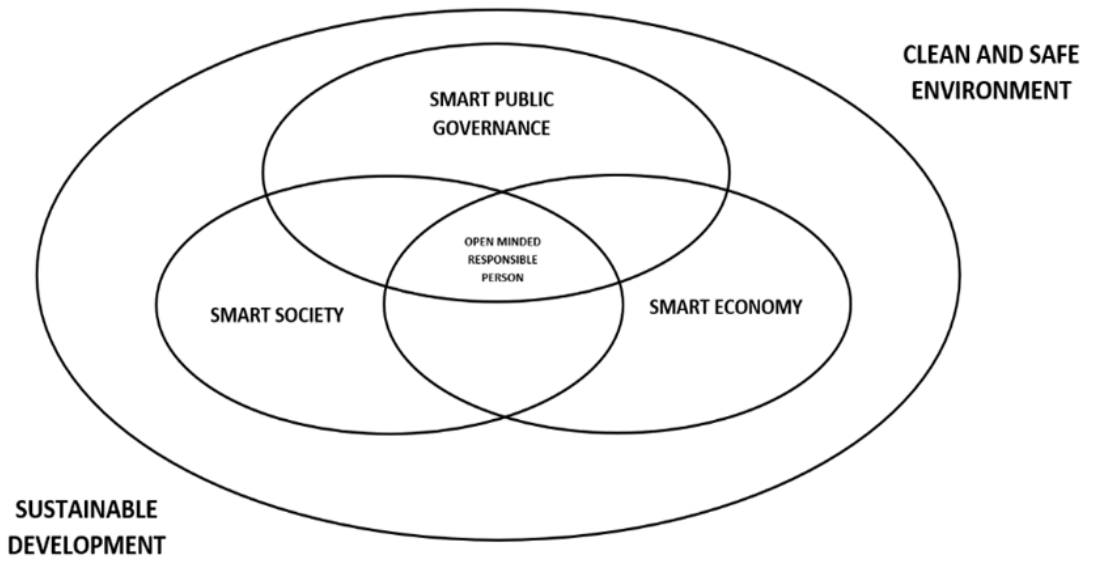

Fig. 3 Model of Lithuania's Progress Strategy “Lithuania 2030”, Source: [10] 
The three areas of the region as a socio-territorial system identified in Sinkienè and Grumadaite's model interact in a specific cultural environment, one expression of which is the built environment (infrastructure, etc.) necessary to achieve the common goal of the members of the regional community - high quality of life and activities.

Sinkienè [8] proposes that the region "should be considered, according to the selected socioeconomic and cultural criteria, a unique and homogeneous space (territory) with defined boundaries, performing the political and/or administrative functions of a state sub-national level". Therefore, in this article, the concept of a smart region is also considered appropriate for the concept of a smart municipality as a territorial unit.

\section{THE TRAJECTORY OF CHANGE IN THE EXPRESSION OF MUNICIPAL POTENTIAL IN DEVELOPING A SMART SOCIAL SYSTEM}

In the introduction of the Program of the 18th Government of the Republic of Lithuania, presented by the Prime Minister of the Republic of Lithuania Ingrida Šimonyte, it is stated that "The global pandemic, climate change, globalization, population aging and technological development are changing Lithuania and the world faster than ever before. These global changes not only increase insecurity and anxiety about the future, but also create a sense of commonality that strengthens people's trust in each other and in their state, and gives them hope for a better future." [9]. Under such unusual and changing circumstances that the Prime Minister emphasized in the program, smartness is becoming extremely important. The importance of smartness is also emphasized in Lithuania's progress strategy "Lithuania 2030". In this document, the coherence of the smart society as well as the economy and society is a key driver of progress [10].

The authors of the government program underlined the sustainable development of Lithuanian regions as one of the priorities, or as the authors themselves proposed, one of the missions [9]. They argue that most of the missions presented combine the responsibilities of several ministries, require coordinated efforts by different institutions and the Government of the Republic of Lithuania [9].

The clearly defined trajectory of change of municipalities as a smart social system not only reflects the expression of smartness necessary in this period, corresponds to the aspirations of strategic state documents, but also helps to achieve the priority goals of the 18th Government of the Republic of Lithuania. In his other works, using Sinkienè and Grumadaite’s [7] smart 
region model and adapting it to the dimensions of the smart economy, smart public governance and smart community created by Jucevičius [5] and other authors, the author of the present study performed a semi-structured survey of municipal experts and clarified the current expression of the dimensions of Lithuanian municipalities as a smart social system. It is reflected in Table 2:

Table 2. Summary of the assessment of the full expression of the potential of smart local self-governance

\begin{tabular}{|c|c|c|}
\hline Areas & Dimensions & Evaluation of experts \\
\hline \multirow{11}{*}{ Smart Economy } & Welfare & Good \\
\hline & Openness & Average \\
\hline & Entrepreneurship & Stronger than average \\
\hline & Responsibility & Average \\
\hline & Intelligence & Stronger than average \\
\hline & Green and socially responsible & Average \\
\hline & Digital & Average \\
\hline & Knowledge-driven and innovations & Average \\
\hline & Learning & Good \\
\hline & Agile & Good \\
\hline & Networking & Average \\
\hline \multirow{4}{*}{$\begin{array}{l}\text { Smart Public } \\
\text { Governance }\end{array}$} & Strategic dynamism & Average \\
\hline & Cross-sectoral collaboration & Average \\
\hline & Inter-sectoral collaboration & Stronger than average \\
\hline & Empowered citizenship & Average \\
\hline \multirow{9}{*}{$\begin{array}{l}\text { Smart } \\
\text { Community }\end{array}$} & Intelligent & Stronger than average \\
\hline & Digital & Weaker than average \\
\hline & Knowledge driven & Weaker than average \\
\hline & Learning & Weaker than average \\
\hline & Networked & Average \\
\hline & Innovative & Average \\
\hline & Sustainable & Weaker than average \\
\hline & Agile & Average \\
\hline & Socially responsible & Stronger than average \\
\hline
\end{tabular}

Source: prepared by the author according to the statements of experts 
On June 10, 2020, the government approved the DNA plan for the future economy prepared by the Ministry of Finance. When approving the plan, the then Minister of Finance Vilius Šapoka stated that "at the beginning of the COVID-19 crisis, we allocated funding for short-term measures to stabilize the situation, and we continue to work with investments for the future. The global changes taking place in the world economy are a great opportunity for Lithuania, which we have and can use. Accelerating already planned investments and attracting new investments in strategically important areas, provide opportunities for us to recover from a pandemic and change the DNA of our country's economy. Therefore, we must act quickly and efficiently." [11]. The Minister only once again testifies that in an uncertain and constantly changing environment we have to act quickly and efficiently, i.e. in a smart way.

To implement this plan by the end of 2021, it is planned that around $€ 6.3$ billion of longterm investments will be allocated, of which new and additional investments will amount to $€ 2.2$ billion, the remaining $€ 4.1$ billion - accelerated and already planned investments [11]. Further in the work, analysing the trajectory of change of smart local self-governance as a smart social system, the author of the article, after analysing the results of academic research, documents and expert interviews, presents proposals according to the formed DNA plan. The presented proposals should help to achieve the state of smart local selfgovernance change trajectory - the desired change (Fig. 4):

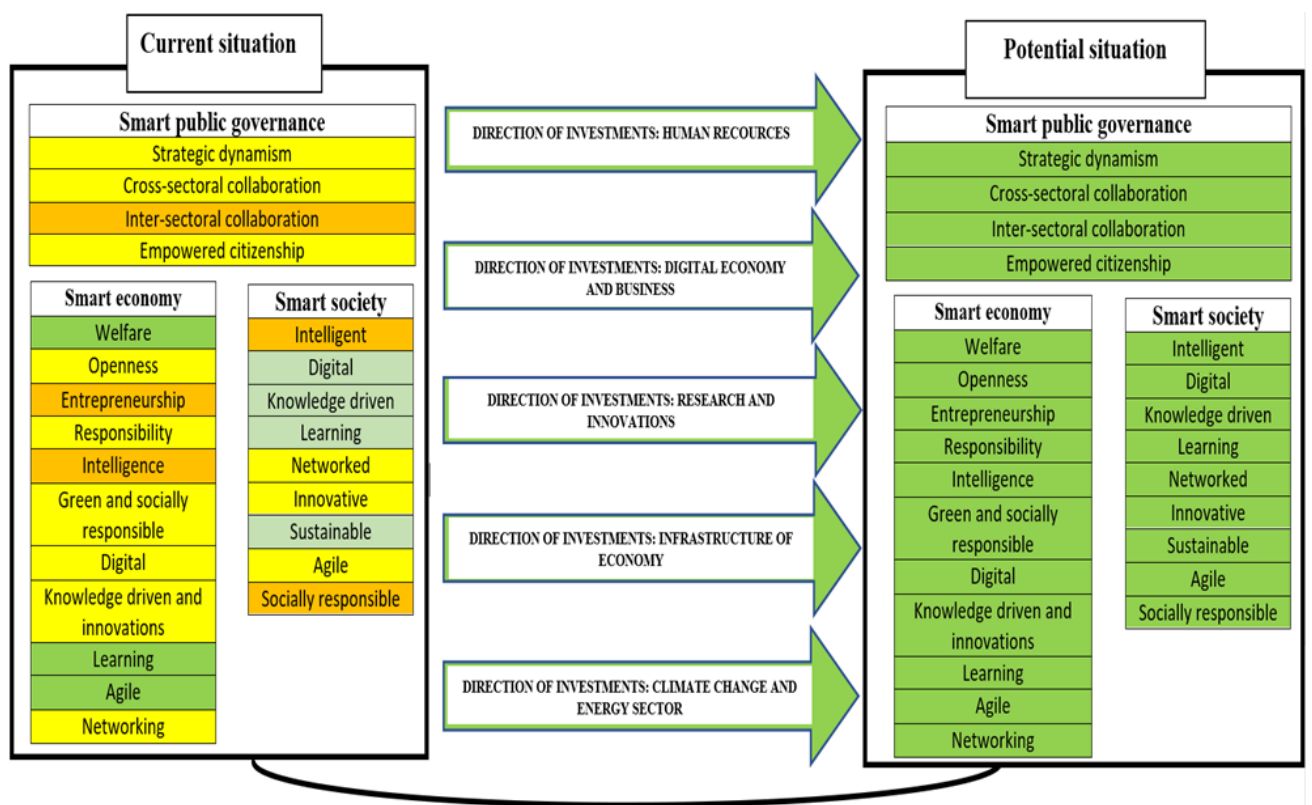

Fig. 4 Trajectory of Smart Local Self-Governance Change, Source: prepared by the author according to experts' statements and content analysis of documents 
When planning action measures according to the first direction of the DNA plan human resources and aiming at a stronger expression of local self-governance as a smart social system, more investment should be made in the leadership of leaders in local selfgovernance and in the development of the competencies of people working in the public sector in general. This solution would help to achieve a better expression of the strategic dynamism dimension and contribute to strengthening the rapid response dimension. The need to strengthen leadership and rapid response was also noted by the experts who were interviewed.

The second direction of the planned DNA plan investments is the digital economy and business. The improvement of digitization in business structures and society in general would help to achieve the potential of smart self-governance. As experts point out, these funds should be used to invest in the development and implementation of a strategy for digitization and smart regions. It is also worth investing in a better functioning expert advice system. This would help businesses save resources and strengthen the expression of the strategic planning and response dimensions.

The third direction of the DNA plan envisages significant investment in innovation and research. These additional investments could help to strengthen the expression of the knowledge and innovation dimension at the local self-governance level. However, investment in innovation alone is not enough. Funds should also be directed towards promoting better cooperation between business and science, as there is still a lack of cooperation and incentives. Initiatives to encourage the public to use the latest technologies should also be borne in mind when planning investments in this area. The development of these competencies in society would not only help the government to get better feedback on the decisions made, but also raise their quality, as well as increase the number of consumers who value and use innovation, i.e. demand.

The fourth and fifth directions are economic infrastructure as well as climate change and energy. Sustainability and public incentives for environment protection should be encouraged when planning these investments.

When planning any investment, the benefits of cooperation and the identification and dissemination of good practice, the promotion of initiative have to be taken into consideration. In particular, it would help to strengthen the expression of the learning and networking dimensions and contribute to the strengthening of innovation. 
Of course, not all the proposed measures will be implemented quickly, and often the result will only be visible over a longer period of time. Also, as pointed out by the promoters of the 18th Government of the Republic of Lithuania, a breakthrough in certain areas often requires close coordination between different institutions. Unfortunately, as a survey of experts has shown, there is still a lack of successful inter-institutional cooperation in Lithuania. However, the current era requires a special expression of smartness, the ability to make decisions quickly and efficiently, and the trajectory mentioned in this article would help to improve the expression of smartness at the local self-governance level.

\section{CONCLUSION}

In today's world, the public sector is facing more and more new, unforeseen challenges related to demographic, social, economic, technological, and global challenges. The latest technology and the availability of information are forcing us to keep with new standards of openness and accountability. People's involvement and confidence in the political system are decreasing. In such a situation, the pressure on local authorities and national authorities to adapt to the changing environmental conditions, to make decisions quickly and efficiently, to solve problems is increasing. Therefore, the need for smartness arises. Academics also single out other dimensions that are important for a smart social system. They include smartness, mobility, networking, sustainability, knowledge-driven, innovation, digitalisation, and learning. The need for the expression of smartness in the fields of economy, public governance and society is also provided for in the strategic documents of Lithuania. It was particularly evident in the current Covid-19 pandemic period. In this study, the author, based on the works of authors who have studied smart regions, has analysed the expression of the dimensions of a smart social system at the local self-governance level and presented the trajectory of the desired change.

The author of the article compiled a municipal model of 24 dimensions of smartness. Taking into consideration the 24 dimensions of smartness, their quantitative and qualitative characteristics, a questionnaire was compiled, a survey of self-governance experts was conducted that helped to establish the expression of these dimensions in the current situation of local self-governance. The strongest expression of the dimensions was in the dimensions of the general well-being, learning and rapid response of the smart economy. The weakest expression in the field of smart economy in the dimensions of entrepreneurship and smartness, in the field of smart public governance - in the dimension of inter-institutional 
cooperation, in the field of smart community - in the dimensions of smartness and social responsibility.

In order to recover from the COVID-19 crisis and to achieve a breakthrough in Lithuania, a new DNA plan was approved in June 2020. Within the framework of this plan, huge investments are foreseen, which will have to be absorbed quickly and efficiently, i.e. in a smart way. Based on the analysis of expert attitudes, measures have been proposed to increase the potential of local self-governance as a smart social system.

\section{REFERENCES}

[1] Gaulè, E. (2014). Sumanus viešasis valdymas: samprata ir dimensijos. Viešoji politika ir administravimas, vol. 13 , no. 3, p. 372-385.

[2] Buškevičiūtè, J. (2014). Sumaniojo viešojo valdymo koncepcijos paieškos: skirtingų teorinių prieigų kritinè analizè. Viešoji politika ir administravimas, vol. 13, no 3, p. 359-371.

[3] Jucevičienè, P., Jucevičius, R. (2014). What does it mean to be smart? In: Business and management 2014: the 8th international scientific conference, May 15 - 16, 2014, Vilnius, Lithuania: selected papers, vol. 2, Vilnius Gediminas Technical University, Riga Technical University, p. 911-918.

[4] Jucevičius, R., Jucevičienè, P. (2017). Sumaniosios socialinès sistemos koncepcija. Kn.: Jucevičius, R. ir kt. Sumanioji socialinè sistema. Kaunas: Technologija, p. 12-34.

[5] Jucevičius, R. (2014). Sumaniojo miesto vystymo strateginės dimensijos. Viešoji politika ir administravimas, vol. 13, no. 3, p. 427-441.

[6] Stanislovaitienè, J. (2016). Sumaniojo viešojo valdymo dimensiju raiška: Lietuvos atvejis. Daktaro disertacija. Kaunas: Kauno technologijos universitetas.

[7] Sinkienè, J., Grumadaitè, K. (2014). Sumanaus regiono konceptualusis modelis. Viešoji politika ir administravimas, vol. 13, no. 3, p. 414-426.

[8] Sinkienè, J. (2017). Sumanusis miestas ir regionas. Kn.: Jucevičius, R. ir kt. Sumanioji socialinè sistema. Kaunas: Technologija, p. 149-166.

[9] Dèl Lietuvos Respublikos vyriausybès programos (2020). Prièmė Lietuvos Respublikos Seimas 202012 11, Nr. XIV-72, from: https://e-seimas.lrs.lt/portal/legalAct/lt/TAD/ 973c87403bc311eb8c97e01 ffe050e1c?jfwid=-ez0kdk5cl

[10] Lietuvos pažangos strategija „Lietuva 2030“ (2012). Patvirtinta Lietuvos Respublikos Seimo nutarimu $2012 \mathrm{~m}$. gegužès 15 d. no. XI-2015, from: https://eseimas.lrs.lt/portal/legalAct/lt/TAD/TAIS.425517; 
T. Martinaitis; Vol.5.Iss.1. (May.2021) 11 - 21

[11] Vyriausybejje patvirtintas ateities ekonomikos DNR planas (2020). Lietuvos Respublikos Finansų ministerija. From: https://finmin.lrv.lt/lt/naujienos/vyriausybeje-patvirtintas-ateitiesekonomikos-dnr-planas 